\title{
POLICY NOTE
}

\section{AFGHANISTAN'S}

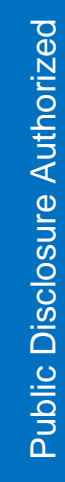

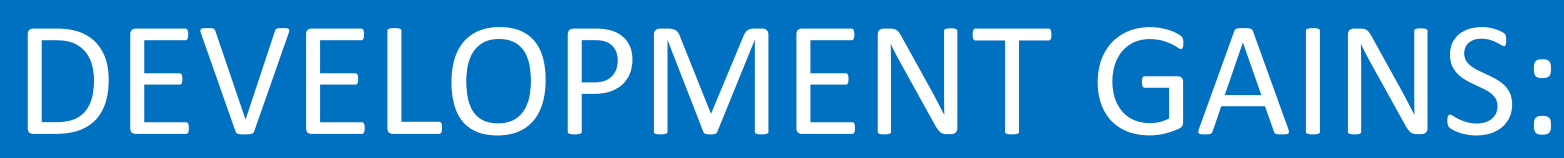

Progress and challenges

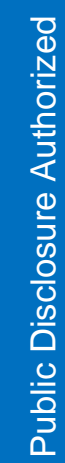

(7) THE WORLD BANK 


\section{Disclaimer}

This volume is a product of the staff of the International Bank for Reconstruction and Development/The World Bank. The findings, interpretations, and conclusions expressed in this paper do not necessarily reflect the views of the Executive Directors of The World Bank or the Governments they represent. The World Bank does not guarantee the accuracy of the data included in this work. The boundaries, colors, denominations, and other information shown on any map in this work do not imply any judgment on the part of The World Bank concerning the legal status of any territory or the endorsement or acceptance of such boundaries.

\section{Copyright statement}

The material in this publication is copyrighted. Copying and/or transmitting portions or all of this work without permission may be a violation of applicable law. The International Bank for Reconstruction and Development/The World Bank encourages dissemination of its work and will normally grant permission to reproduce portions of the work promptly.

For permission to photocopy or reprint any part of this work, please send a request with complete information to the Copyright Clearance Center, Inc., 222 Rosewood Drive, Danvers, MA 01923, USA, telephone 978-750-8400, fax 978-750-4470, http://www.copyright.com/.

All other queries on rights and licenses, including subsidiary rights, should be addressed to the Office of the Publisher, The World Bank, 1818 H Street NW, Washington, DC 20433, USA, fax 202-522-2422, e-mail pubrights@worldbank.org.

\section{Acknowledgements}

This note was prepared by Tobias Haque (Senior Country Economist, GMTSA) under the guidance of Manuela Francisco (Practice Manager, GMTSA) and Henry Kerali (Country Director, SACKB). Valuable comments and inputs were provided by Walker Bradley (Geographer), Cesar Cancho (Poverty Economist), Nandini Krishnan (Senior Poverty Economist), Ayo Akala (Senior Health Specialist), Guillemette Jaffrin (Program Leader), Hamid Quraishi (Energy Specialist), and Fanny Missfeldt-Ringius (Lead Energy Specialist). 


\section{'---------------------------------------- \\ HIGHER INCOMES}

$\$ 1,800$

$\$ 1,027$

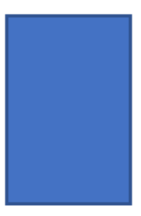

2002
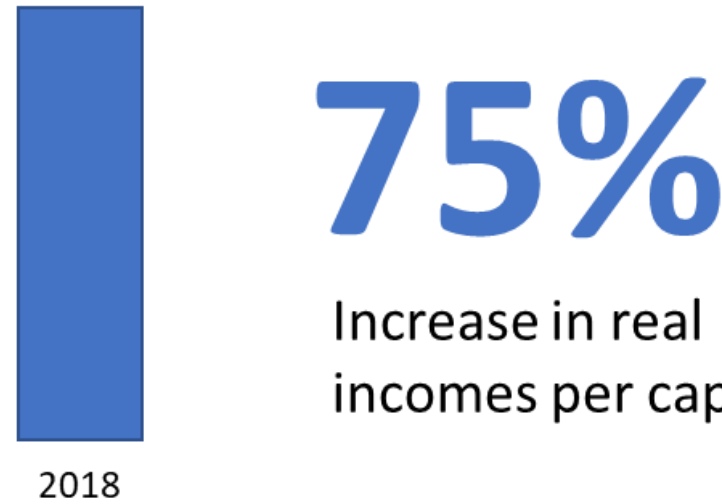

Increase in real incomes per capita

\section{MORE CHILDREN IN SCHOOL}
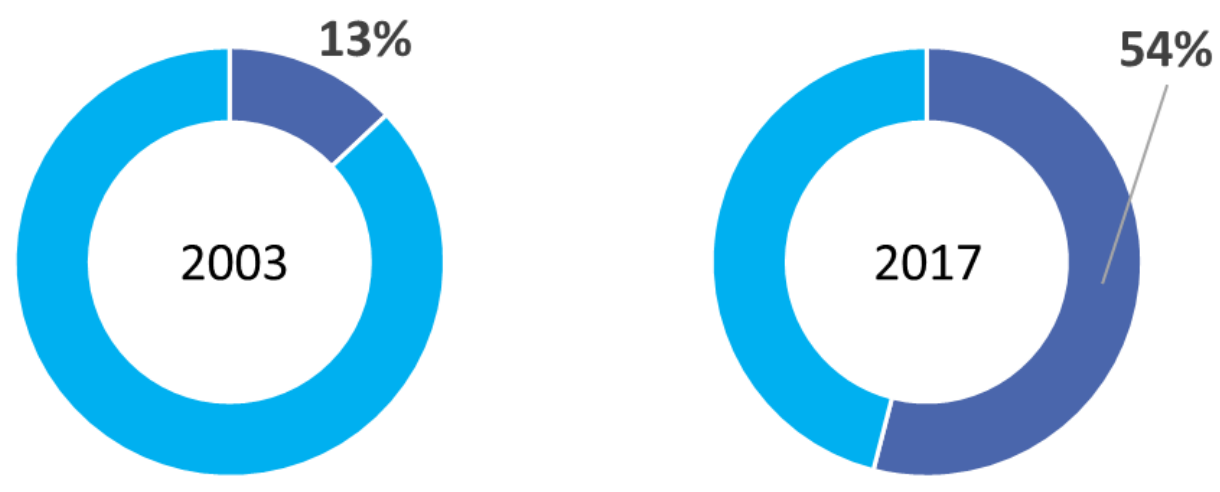

Proportion of secondary-age children enrolled in secondary education (9. 2 million more children in school 


\section{REDUCED MATERNAL MORTALITY}

\section{1,100}

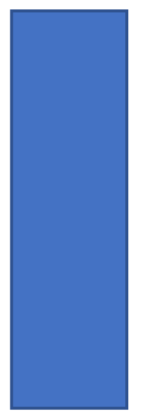

2002
Deaths per

396100,000 live births.

\section{REDUCED CHILD MORTALITY}

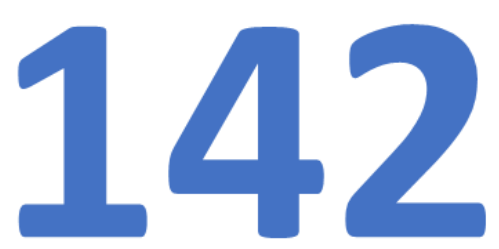

more children surviving to the age of five for every 1,000 births 


\section{MORE LITERATE YOUTH}

\section{Youth literacy rate}
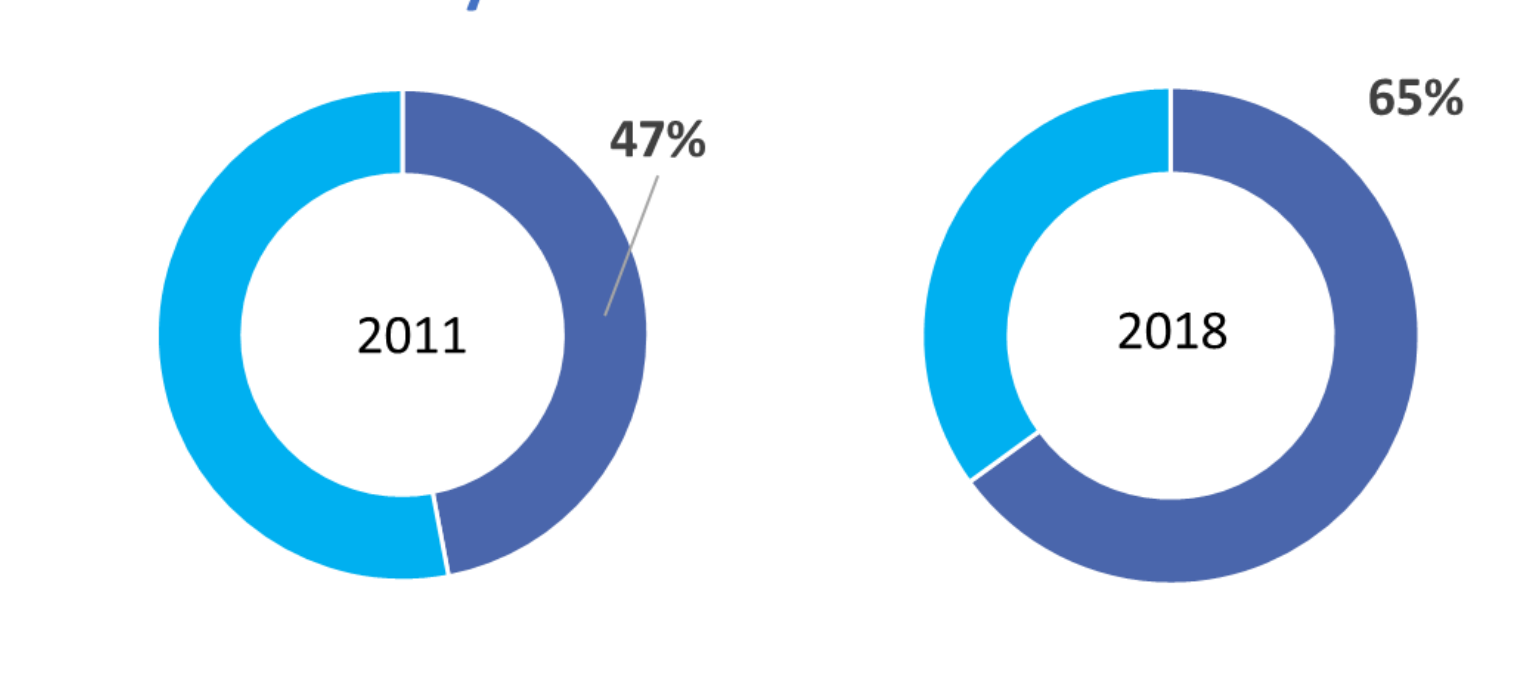

\section{LOWER FERTILITY}

Births per woman

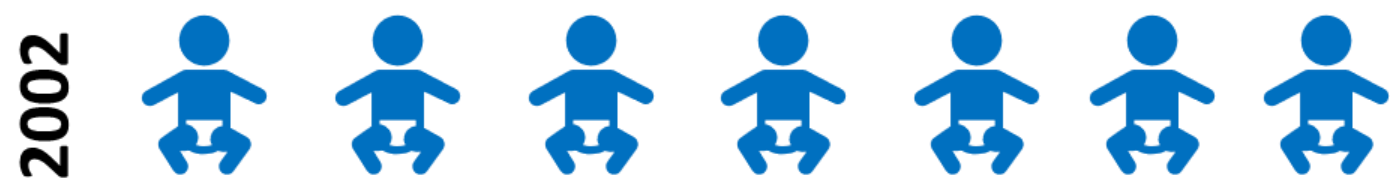

$$
\begin{aligned}
& 7.3
\end{aligned}
$$

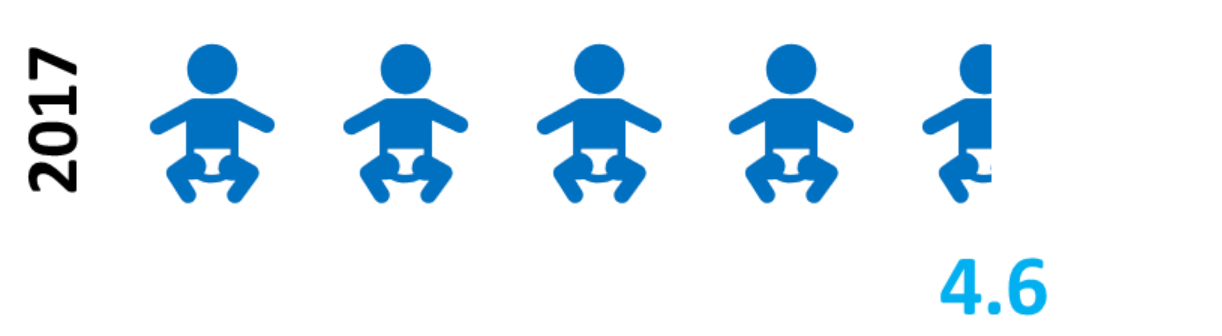




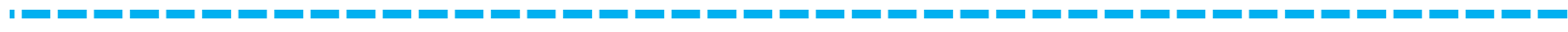 \\ HIGHER REVENUES}
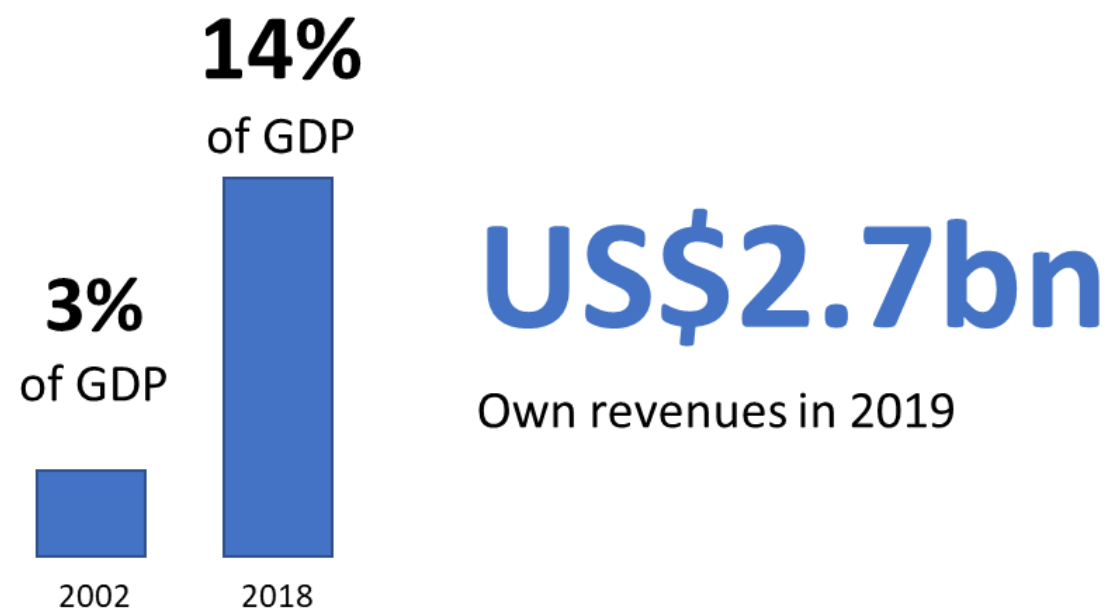

Own revenues in 2019

\section{BETTER ACCESS TO ELECTRICITY}

Connections to the grid

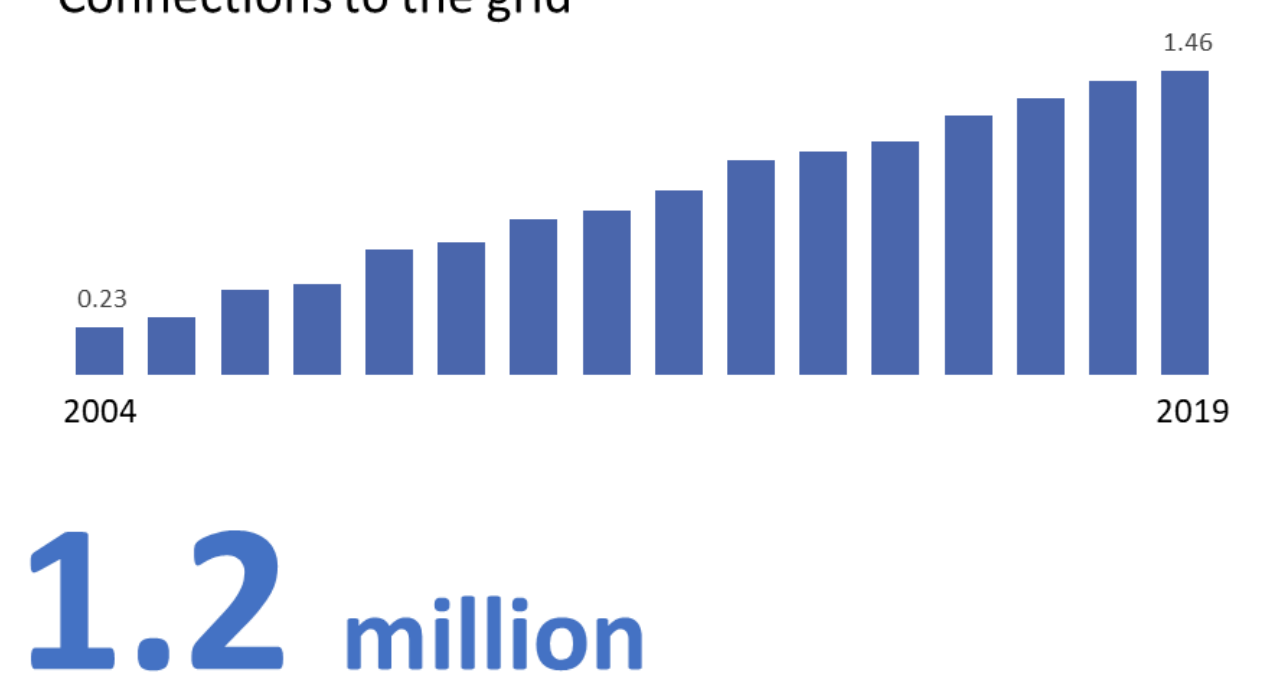

New electricity grid connections 


\section{Executive Summary}

The international community has invested heavily in Afghanistan

\section{Macroeconomic management has remained strong}

Many development
outcomes have
improved rapidly
since 2001, especially
when compared
against other low-
income countries

Gains remain fragile

Continued support is needed
The international community has invested heavily in Afghanistan since 2001. A relatively small proportion of this investment has been in civilian aid for reconstruction and development. During certain periods, civilian aid to Afghanistan has been very high, but flows have recently declined to levels comparable with other low-income countries. Afghanistan's heavy aid dependence is now driven primarily by high security grants.

Strong macroeconomic management by government has established an enabling environment for improved development outcomes. Economic growth has been rapid, supporting rapid growth in incomes. Government policy has ensured that inflation has remained moderate, deficits have been limited, and public revenues have grown rapidly.

Afghanistan remains mired in conflict and faces immense development challenges. While data is imperfect and progress against development outcomes has been uneven and often slower than expected or desired, important gains have been achieved. While poverty remains high and has recently increased, it is likely that incomes remain much higher than they were in 2001. Expanded access to health, education, and infrastructure has seen rapid improvements in outcomes, with Afghanistan catching up with other low-income countries against key development indicators. The position of women has improved, including through improved access to education and representation within the civil service and politics.

Gains remain fragile. Positive progress against many development outcomes is not being matched with progress in strengthening governance and institutions. Many access and outcome indicators have shown deterioration since 2012, with deteriorating security conditions, declining aid inflows, and economic slow-down. There is limited scope to further expand government revenues without faster economic growth, while grants continue to finance around 75 percent of public expenditure.

The development gains that Afghanistan has achieved over recent years will therefore only be sustained if reductions in grant support are gradual and carefully calibrated. A precipitous reduction in grants would undermine the capacity of government to sustain service delivery, leading to deteriorations in education, health, and well-being. In order to maintain the confidence of the international community and provision of international grant support, Government needs to take decisive action to address corruption and improve governance. Efforts should be taken in partnership between Government and the international community to: i) identify specific and measurable goals for anti-corruption and institutional strengthening that represent shared priorities; and ii) mobilize coordinated efforts to achieve those goals, drawing on international assistance as needed. 


\section{Introduction}

Afghanistan has achieved major gains since 2001
This note outlines some of the major gains that have been achieved in Afghanistan since the US-led intervention in 2001. The analysis is informed by comparisons to development progress and outcomes in other low-income countries over the same period.

Afghanistan remains mired in conflict and faces immense development challenges. However, donor and government programs executed in the context of rapid economic growth and sound macroeconomic management have supported rapid improvements in provision of basic public services and infrastructure over the past two decades. While progress has been uneven and data to assess progress is sometimes limited or unreliable, increased access to services and infrastructure has driven huge development gains, often far outpacing progress achieved in other low-income countries. Against many indicators, Afghanistan is now performing similarly to other countries at its level of incomes, while receiving similar levels of civilian aid. Development gains remain fragile, however, and continued international support will be required to avoid reversal of recent progress.

Section two outlines the extent of international assistance to Afghanistan since 2001. Section three reviews economic performance and overall macroeconomic management. Section four shows how access to services and infrastructure has improved. Section five shows how improved access to services has led to major improvements in development outcomes, including for women. The final section highlights continued weakness in governance and the need for ongoing international support.

\section{International Support to Afghanistan}

\begin{abstract}
Afghanistan has received substantial international aid support since 2001
\end{abstract}

International support to Afghanistan since 2001 has taken several forms, including: i) direct military and counter-terrorism activity by international partners; ii) grant support to Afghanistan security agencies; and iii) civilian aid for development and reconstruction. While data constraints preclude detailed disaggregation, it is clear that civilian aid spending has constituted only a small share of total expenditure by the international community. For example, the Brown University Costs of War project estimates that the US has spent a total of US\$ 2 trillion in Afghanistan since 2001. This compares to total civilian aid spending from all international partners of around US\$70 billion since 2001, according to OECD DAC data.

Relative to other low-income countries, Afghanistan has received very high levels of civilian aid during certain periods since 2001. Per capita civilian aid peaked in 2007 at US $\$ 228$. But civilian aid flows have since declined substantially, to around US $\$ 105$ in 2017 within the range of aid flows to other low-income countries. Afghanistan is receiving similar per capita civilian aid as several countries with significantly higher incomes (Yemen, Haiti) and less aid than other countries at similar income levels (Liberia, South Sudan). 
While Afghanistan remains extremely reliant on aid relative to other low-income countries, this is largely due to very high levels of security grants which help finance a very large security sector. Security grants account for around 60 percent of total grants to Afghanistan. Security spending is equal to around 30 percent of GDP compared to an average of around three percent of GDP in other lowincome countries.

Figure 1: Afghanistan has received high levels of civilian aid, but flows have substantially decreased

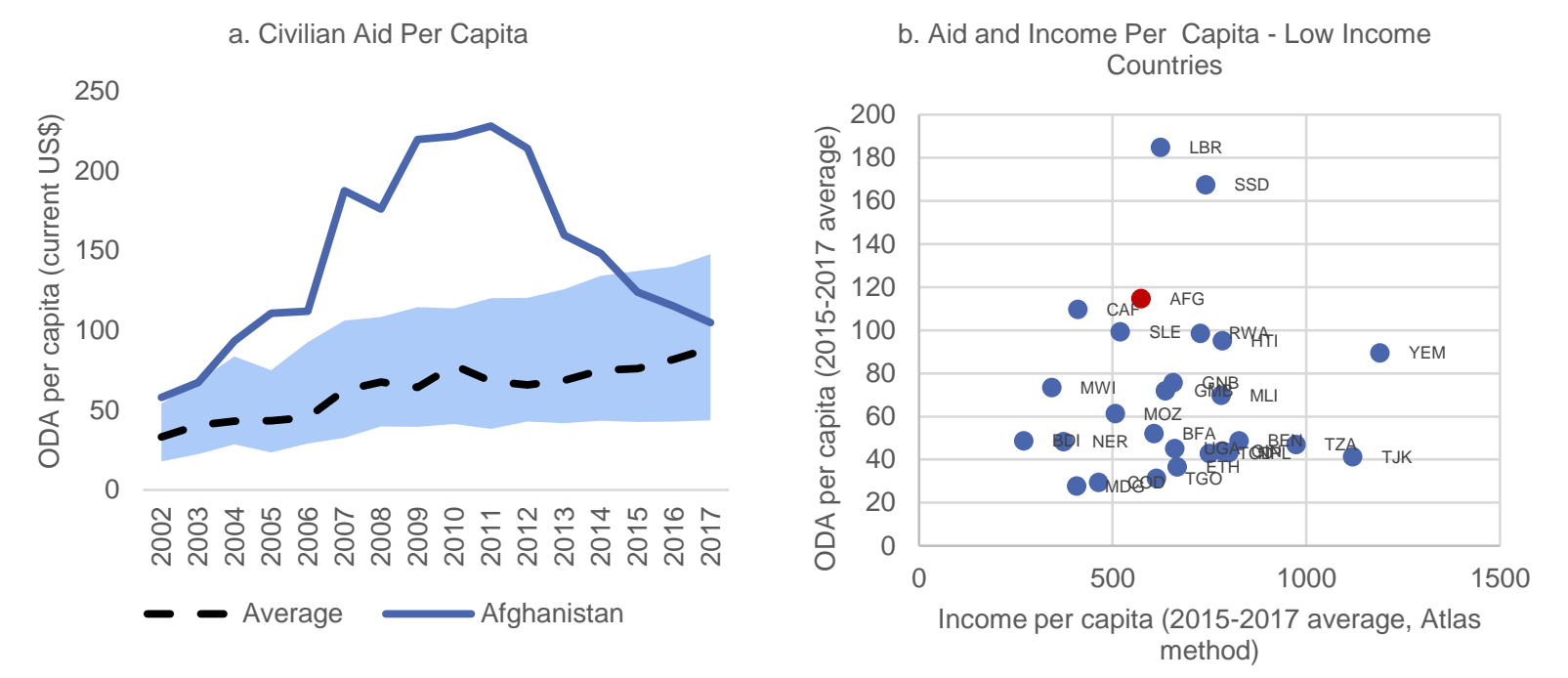

Sources: OECD DAC, World Bank staff calculations

Note: Average is for all low-income countries. Shaded band shows $25^{\text {th }}$ and $75^{\text {th }}$ percentile.

\section{Economic development and macroeconomic management}

Afghanistan's economy has grown rapidly since 2001 , driving much higher incomes
While recent growth rates have been modest, Afghanistan's economy has expanded considerably since 2001. Aid influx has spurred rapid growth in services, while restoration of infrastructure has supported recovery in broader production, especially agriculture. Afghanistan's average annual real GDP growth between 2001 and 2018 was among the fastest across low-income countries (nearly seven percent). Real per capita incomes increased by 75 percent, with income per capita increasing from around 70 percent of the low-income country average to 107 percent of the low-income country average. 


\section{AFGHANISTAN'S DEVELOPMENT GAINS}

Figure 2: Afghanistan has experienced rapid economic growth, on average, since 2001

a. Average Real GDP Growth

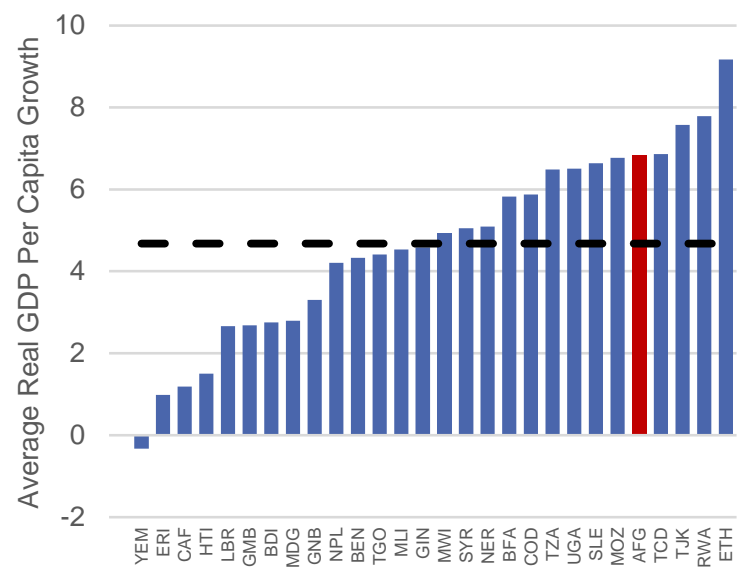

b. Real GDP Per Capita

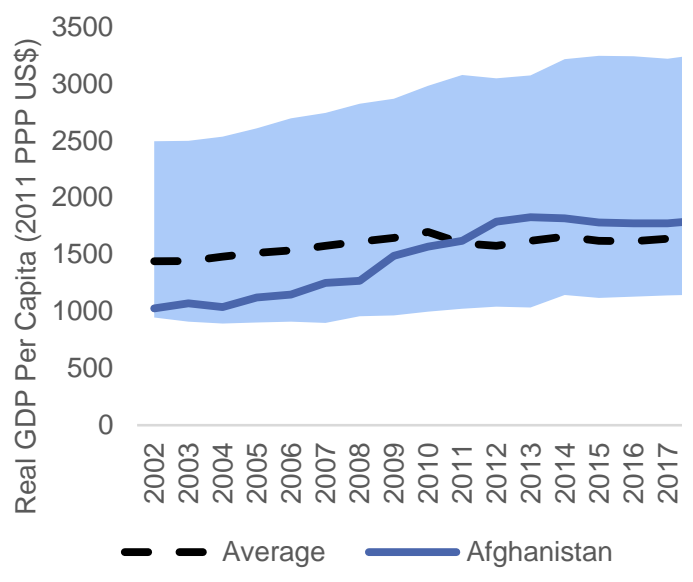

Sources: World Development Indicators

Note: Average is for all low-income countries. Shaded band shows 25th and 75th percentile.

Figure 3: Afghanistan's economy has grown faster than other low-income countries, and incomes are now above the low-income country average

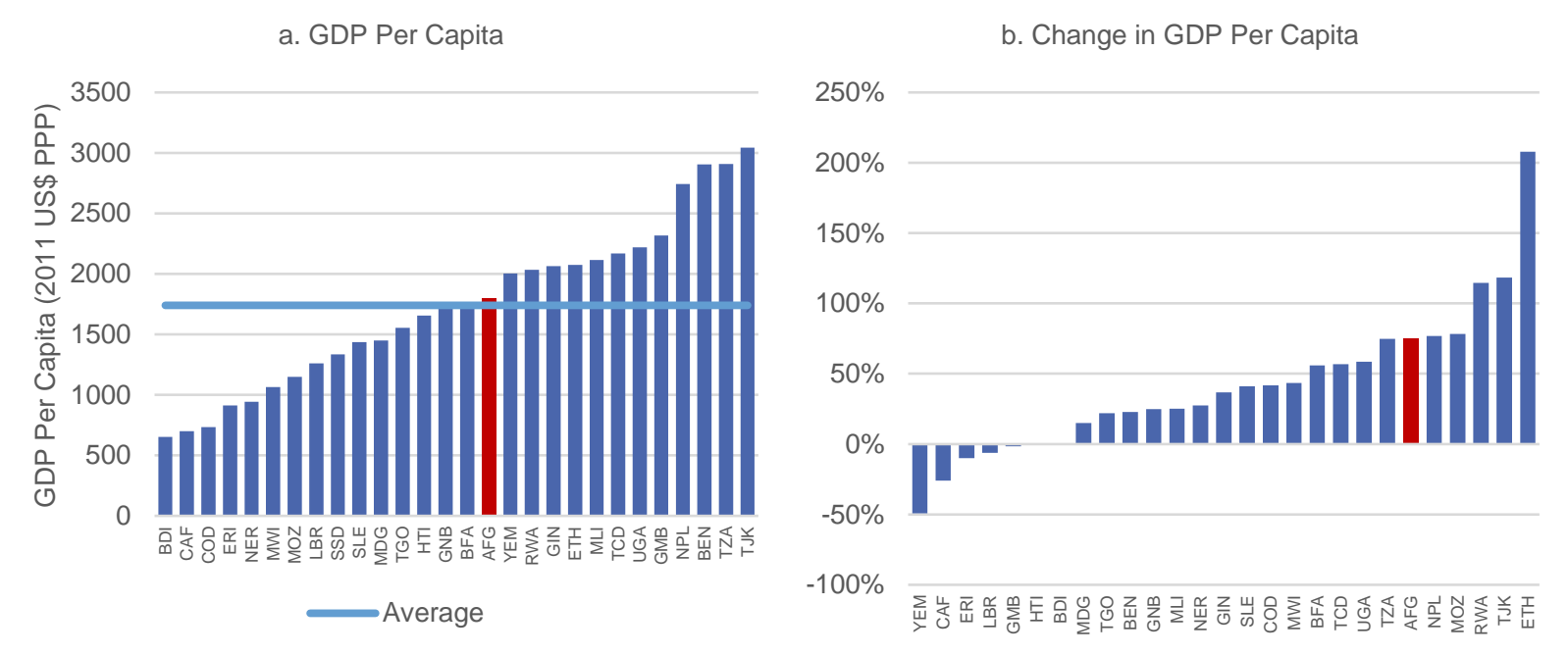

Sources: World Development Indicators, World Bank staff calculations

Through sound

economic

management,

inflation has

remained relatively

low
With sound management of the money supply by Da Afghanistan Bank and the maintenance of overall fiscal discipline by the Ministry of Finance, inflation has remained moderate since 2002. Inflation in Afghanistan has averaged around six percent since 2002, compared to nine percent for low-income countries and around 10 percent of other fragile low-income countries.

Inflation has been particularly low in Afghanistan over the past five years, averaging just three percent, relative to 10 percent for low-income countries and 14 percent for fragile low-income countries. 


\section{AFGHANISTAN'S DEVELOPMENT GAINS}

Figure 4: Inflation has remained relatively low in Afghanistan Average annual inflation (percent)
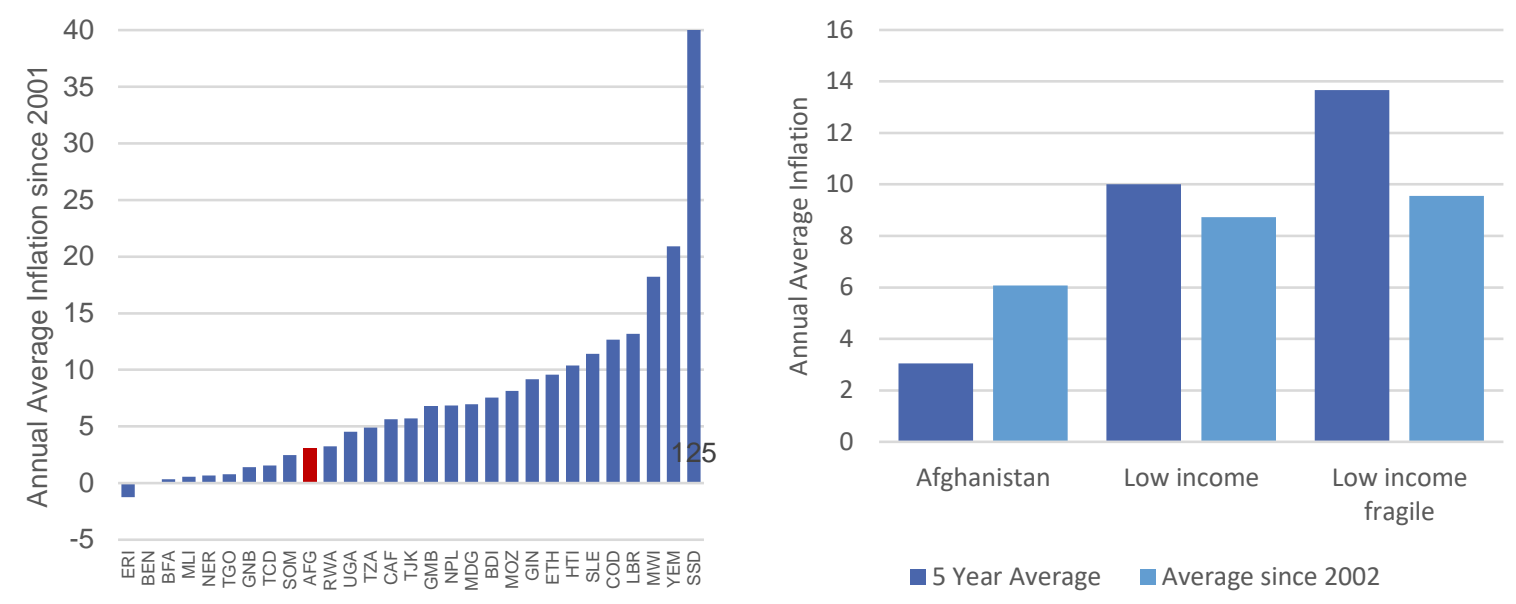

Sources: World Development Indicators

Government revenues have grown very rapidly
Since 2002, Afghanistan has seen remarkable growth in government revenues through the establishment of an effective revenue system. Unlike in many other low-income countries, revenue growth has been driven through taxation of dispersed economic activity, rather than taxation of natural resource projects. Revenues have grown from just three percent of GDP in 2002 to around 14.5 percent of GDP today - equal to the average for low-income countries.

Revenue performance has been especially impressive since 2014, when Afghanistan experienced a revenue collapse during the previous presidential elections. Since 2014, revenues have grown by around six percentage points of GDP. This is the fastest rate of revenue growth for any low-income country over this period, other than Nepal.

Figure 5: Revenues have grown from negligible levels to reach the low-income country average

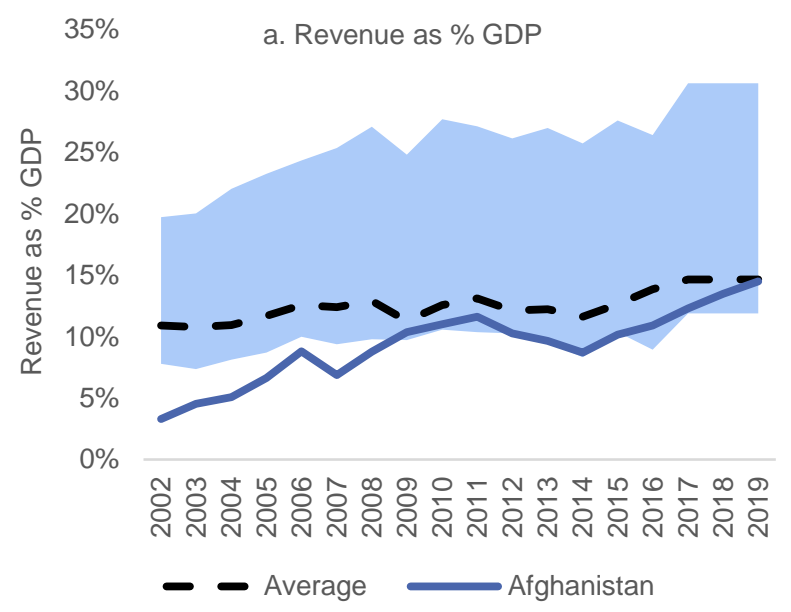

b. Change in revenue since 2014

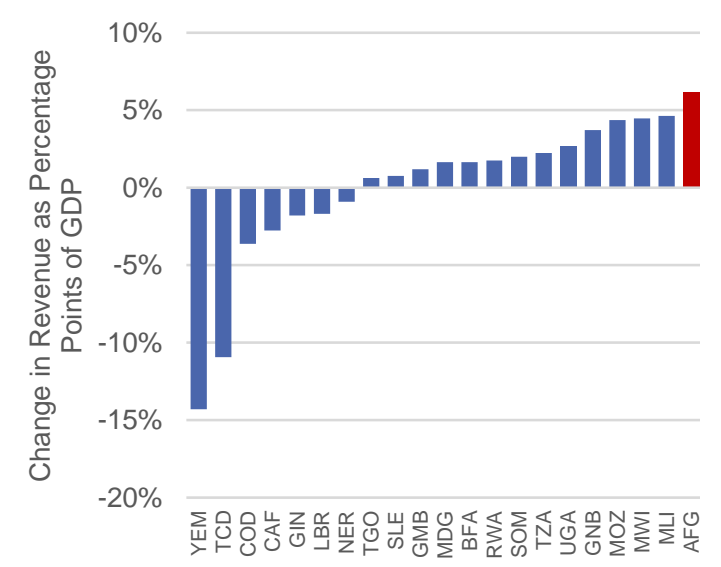

Sources: ICTD/UNU-WIDER, 'Government Revenue Dataset', 2019, https://www.wider.unu.edu/project/government-revenuedataset'

Note: Average is for all low-income countries. Shaded band shows 25 th and 75 th percentile. 
Afghanistan has

avoided

accumulation of debt
Afghanistan had very high levels of debt at the time of the international intervention. Subsequent debt relief provided by international creditors saw debt levels fall to very low levels from around 2006. Since 2006, through prudent fiscal management and constraining budget deficits, Afghanistan has not accumulated significant debt. Afghanistan now has the lowest level of public debt of any lowincome country. Over the past five years, Afghanistan has been one of only five low-income countries not to have experienced an increase in public debt.

Figure 6: Afghanistan has been unusual among low-income countries in avoiding re-accumulation of debt following debt relief in the 2000 s

General Government Gross Debt as \% GDP

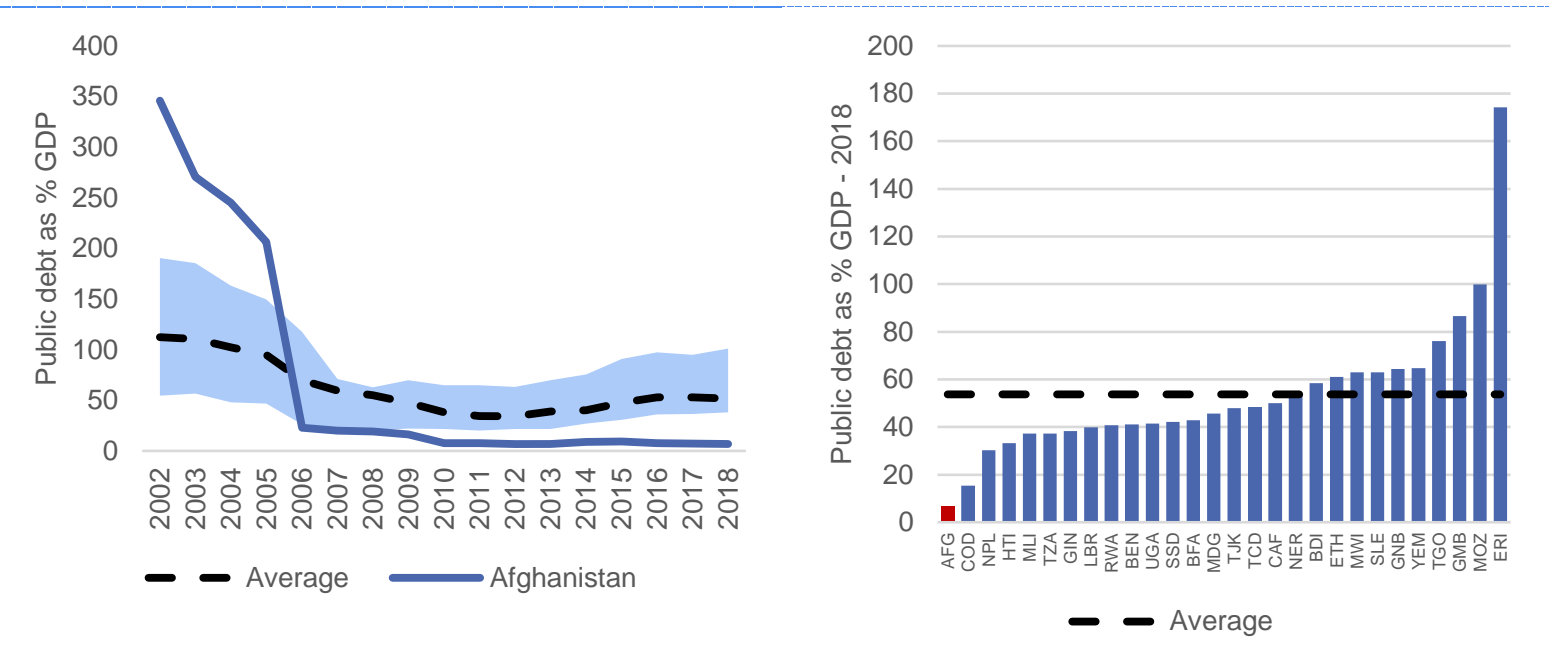

Sources: World Economic Outlook database, World Bank staff calculations

Note: Average is for all low-income countries. Shaded band shows 25 th and 75 th percentile.

\section{Access to services and infrastructure}

Access to services and infrastructure has expanded rapidly
Inflows of aid and rapid improvements in government revenues in the context of sound macroeconomic management have allowed enormous progress in delivering services, despite ongoing active conflict.

Access to health services have improved enormously. The proportion of births attended by a skilled medical professional has increased from just 11 percent in 2003 to around 59 percent in 2018. This is among the fastest pace of progress seen across any low-income country. The proportion of women receiving antenatal care has increased from 16 percent to 65 percent. Progress has been especially impressive in rural areas, where skilled birth attendance increased from four percent to 51 percent, while the proportion of women receiving antenatal care increased from eight percent to 61 percent. 


\section{AFGHANISTAN'S DEVELOPMENT GAINS}

Figure 7: There has been a rapid increase in skilled birth attendance
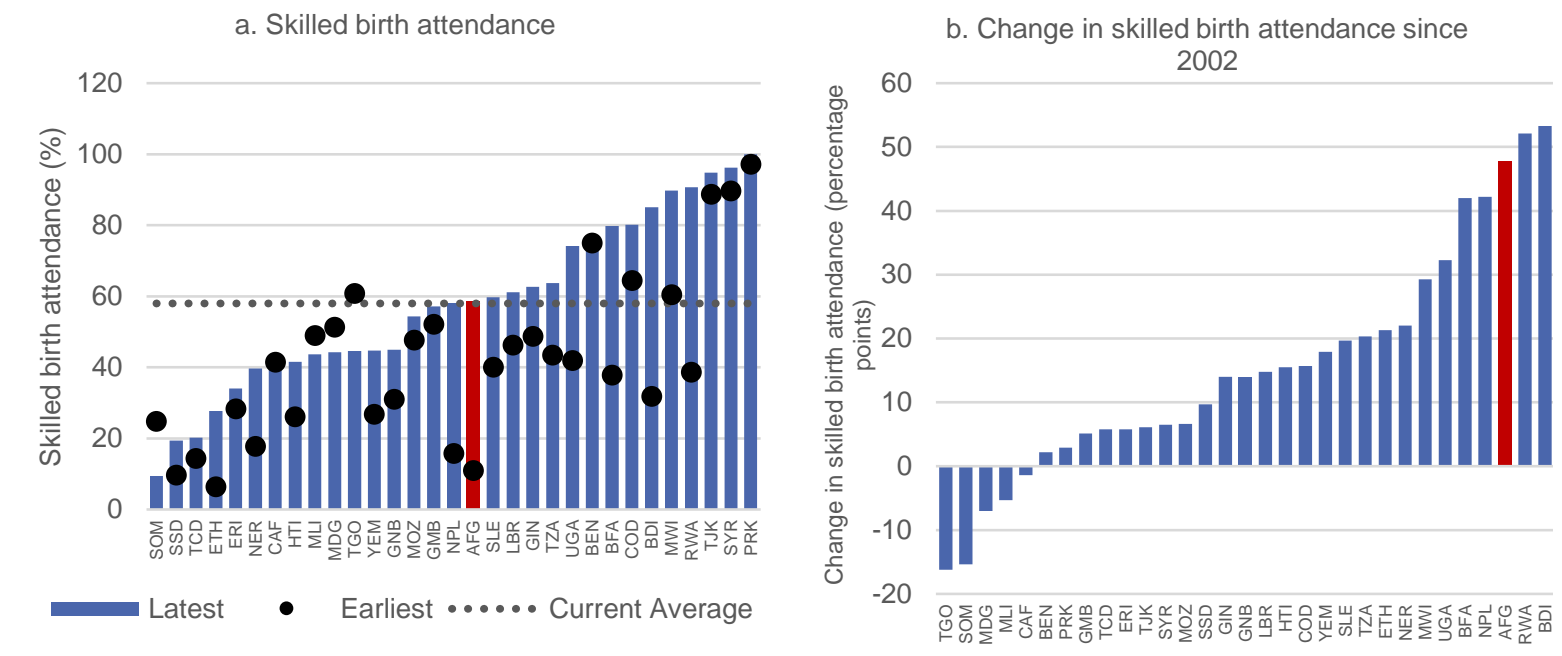

Sources: World Development Indicators, Afghanistan Health Survey (2018)

Note: Change is calculated as the difference between earliest and latest available data-points between 2002-2018. Time periods therefore vary by country.

Access to education has also shown enormous improvement
The number of children attending primary and secondary school has grown rapidly since 2001. By 2016, the number of children enrolled in school was 9.2 million, up from around one million in 2001. ${ }^{1}$ Progress with improved access to secondary education has been particularly impressive. Around 1.7 million children and youth are now attending lower secondary school and 0.9 million attending upper secondary school. The secondary gross enrolment rate has increased from around 13 percent in 2003 to around 54 percent today, well above the low-income country average. This represents one of the fastest rates of increase in secondary enrolment rates seen in any low-income country.

Enrolment rates do not necessarily accurately reflect actual school attendance, as not all enrolled students attend school. Data on school attendance, however, also shows similar positive trends. Between 2007 and 2017, the net secondary attendance rate increased from 26 percent to 35 percent. Average years of schooling increased from 2.0 years to 3.1 years over the same period. ${ }^{2}$

\footnotetext{
${ }^{1}$ World Bank (2018) Promoting Education During Times of Increased Fragility, World Bank, Washington DC.

${ }^{2}$ Afghanistan Living Condition Surveys (2008, 2012, 2014, 2017).
} 
Figure 8: Secondary enrolment rates have grown faster than in any other low-income country since 2001

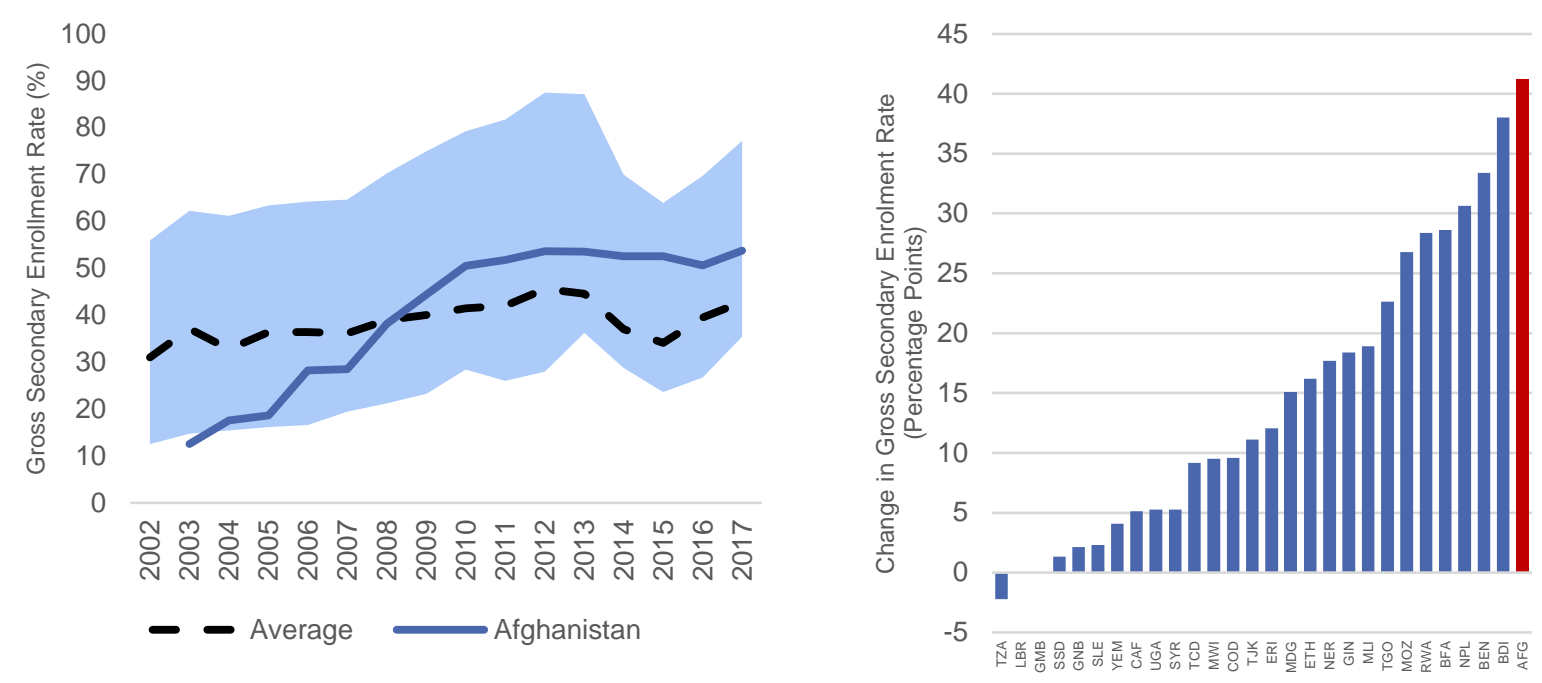

Sources: World Development Indicators, UIS, World Bank staff calculations

Note: Average is for all low-income countries. Shaded band shows 25th and 75th percentile. Change is calculated as the difference between earliest and latest available data-points between 2002-2018. Time periods therefore vary by country.

Access to basic infrastructure has also increased
Donor and government investment in infrastructure has also supported rapid improvements in access to basic services. Infrastructure expansion has also been supported by the establishment of conditions broadly conducive to private sector investment, for example in the telecommunications and solar energy sectors.

The proportion of Afghans with access to electricity has increased rapidly. The number of grid electricity connections has increased from around 228,000 in 2004 to 1.5 million in 2019. The proportions of Afghans with access to grid electricity has increased from around eight percent to around 31 percent between 2004 and 2019. In addition, around 60 percent of Afghans have access to electricity generated from off-grid solar units. ${ }^{3}$

The proportion of Afghans with access to sanitation has increased from 25 percent to 43 percent, well above the low-income country average. Access to mobile phones has kept pace with the massive growth seen across the developing world, with the number of subscriptions increasing from just 0.1 per 100 Afghans in 2002 (about one-tenth of the low-income country average) to 66 per 100 Afghans in 2017 (equal to the low-income country average).

${ }^{3}$ DABS connections data, ALCS 2016/17 data 


\section{AFGHANISTAN'S DEVELOPMENT GAINS}

Figure 9: Access to electricity has increased rapidly, including through expansion of grid connections

a. Proportion of population with access to grid

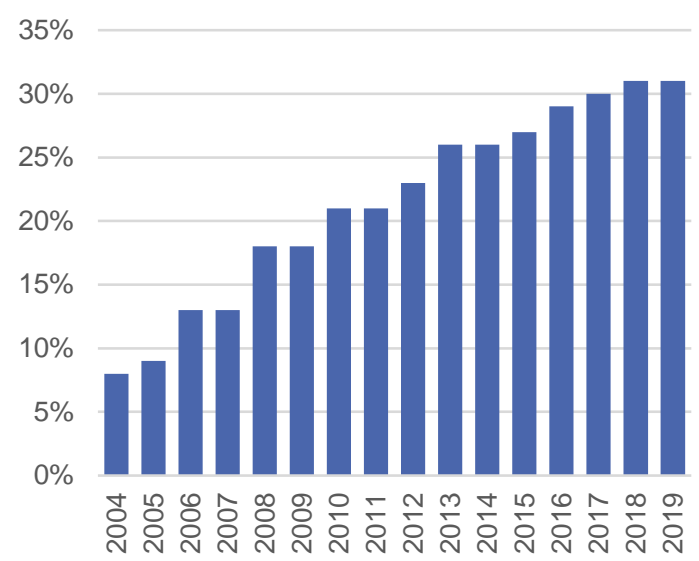

b. Number of electricity connections

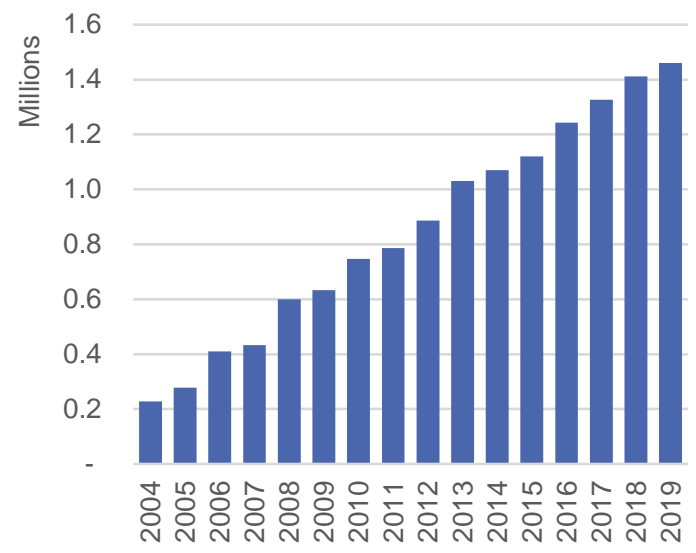

Sources: DABS data, DHS (2015), World Bank staff calculations

Note: Electrification rate is calculated using an assumed houshold size of eight people.

Figure 10: Access to other basic infrastructure has also increased rapidly

\section{a. Mobile phone subscriptions per 100 people}

140

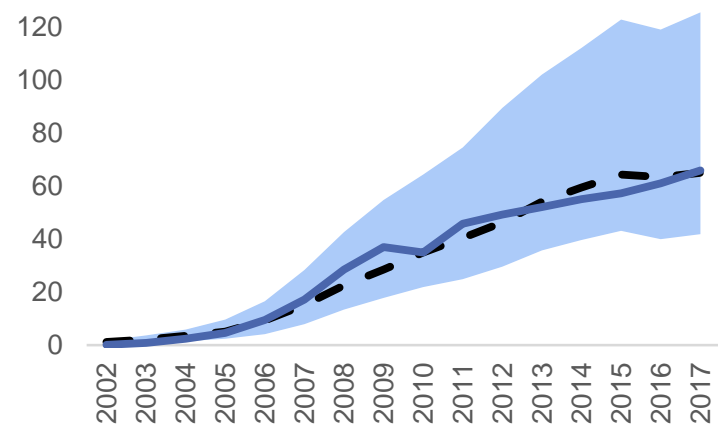

- Average b. Proportion of population using basic sanitation

70

$$
60
$$

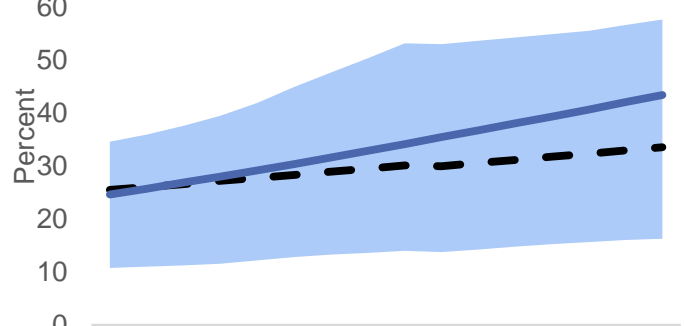

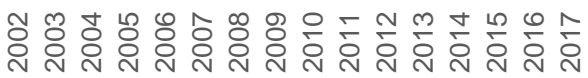

- Average Afghanistan

Sources: World Development Indicators, ALCS (2017)

\section{Development outcomes}

Development outcomes have improved rapidly, but much remains to be done
While poverty remains at unacceptably high levels, expansion in the provision of basic services and infrastructure in the context of a growing economy has driven rapid improvements in development outcomes since 2001. From lagging far behind, Afghanistan has caught up with other low-income countries against key metrics.

Poverty trends since around 2007 have deteriorated, from 34 percent in 20072008 to around 55 percent in 2016-2017, based on the national poverty line. Food insecurity and employment outcomes have also deteriorated, especially in rural areas. There is limited data with which to analyze trends in poverty before 2007, but it seems likely that rapid economic growth and increases in per capita income led to significant poverty reduction over that period. Rapidly increased poverty since 2011-2012 has taken place against the background of slowing economic 
growth and declining per-capita incomes, reflecting the impacts of deteriorating security conditions, declining aid flows, political instability, and climate change.

Full data is not available to accurately compare poverty rates between Afghanistan and other countries using absolute international poverty lines. The rate of poverty in Afghanistan is similar to other low-income countries when using national poverty lines (which vary by country and are therefore not strictly comparable).

Figure 11: Poverty is unacceptably high, and has recently increased Poverty as percent of population using national poverty line

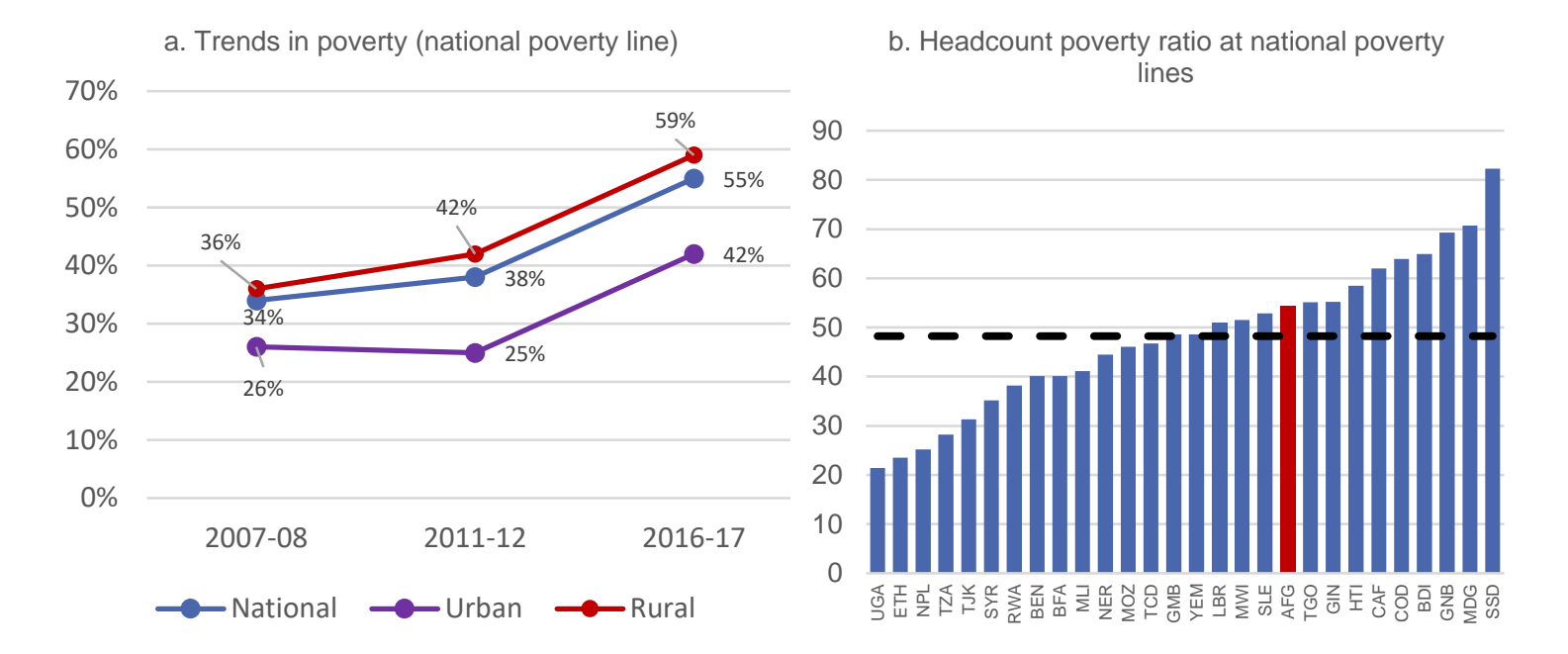

Sources: World Development Indicators, NRVA 2007-08, 2011-12 and ALCS 2016-17

Health and education outcomes have rapidly improved
Improved health services, including maternal and child care, has led to a rapid decline in maternal, infant, and child mortality. ${ }^{4}$ Maternal mortality rates declined from 1,100 to 396 deaths per 100,000 live births between 2000 and $2015 .{ }^{5}$ The under-five child mortality rate has declined from 191 per 1,000 live births in 2007 to 49 per 1,000 live births in 2018.6 No other country has achieved such rapid progress in reducing child mortality over this period, with the number of deaths per 1,000 live births declining by 142 between 2007 and 2018 .

Expansion in access to education has seen rapid improvement in literacy rates. The adult literacy rate has increased from around 28 percent in 2011 (when earliest data is available) to 43 percent in 2018. The youth literacy rate has increased from 47 percent to 65 percent over the same period. While the adult literacy rate remains below the average for Low Income Countries ( 55 percent), Afghanistan has seen very rapid improvement, at a faster pace than achieved by most low-income countries over the same period.

\footnotetext{
${ }^{4}$ Statistics for some health indicators vary by source, reflecting weaknesses in data collection and different methodologies. Most indicators, however, show significant trends of improvement across all sources.

${ }^{5}$ World Bank (2018) Progress in the Face of Insecurity: Improving Health Outcomes in Afghanistan, World Bank, Washington DC.
}

${ }^{6}$ AHS $(2006,2015,2018)$, NRVA $(2008,2013)$, AMS (2010), DHS (2015-2016) 
Reduced child mortality and increased access to education has driven rapid reductions in fertility rates. The total number of births per woman has fallen from 7.3 to 4.6 between 2002 and $2017.7^{7}$ The adolescent fertility rate has also declined from 146 births per 1,000 women between the ages of 15-19 in 2002 to 69 in 2017 - a decline of around 52 percent. Afghanistan's total fertility rate is now around the average for low-income countries, and it has achieved the fastest reduction in fertility rates for any low-income country over the period.

Figure 13: Child mortality has declined in Afghanistan faster than in any other low-income country

a. Under-5 mortality rate

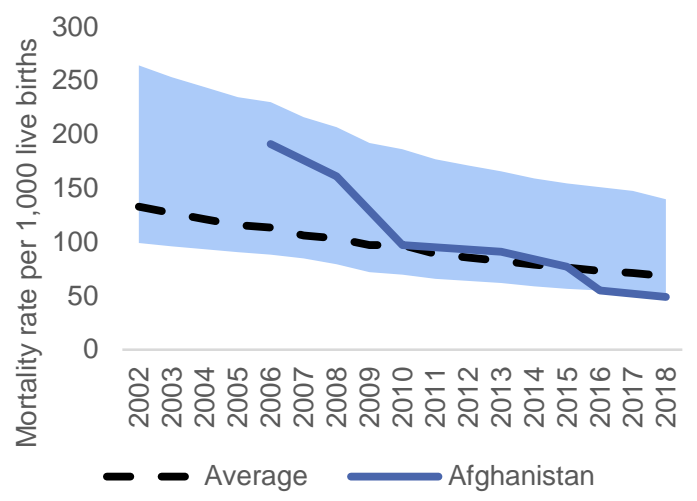

b. Change in under-5 mortality rate

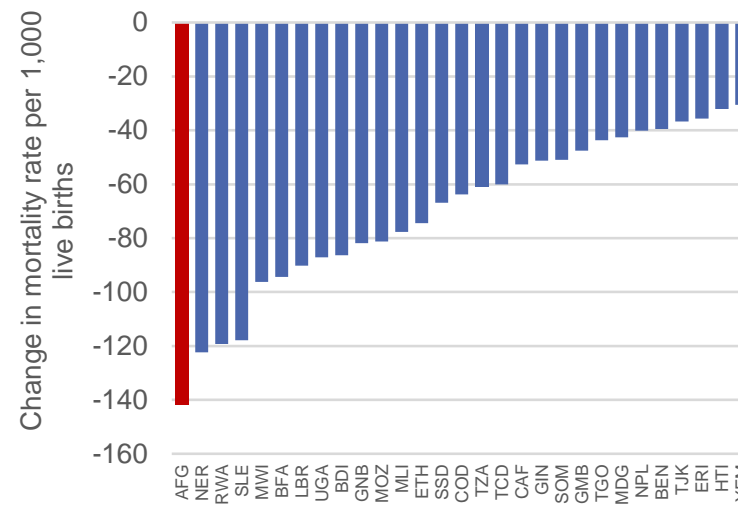

Sources: World Development Indicators, AHS (2006, 2015, 2018), NRVĀ (2008, 2013), AMS (2010), DHS (2015-2016)

Figure 14: Literacy rates have rapidly increased

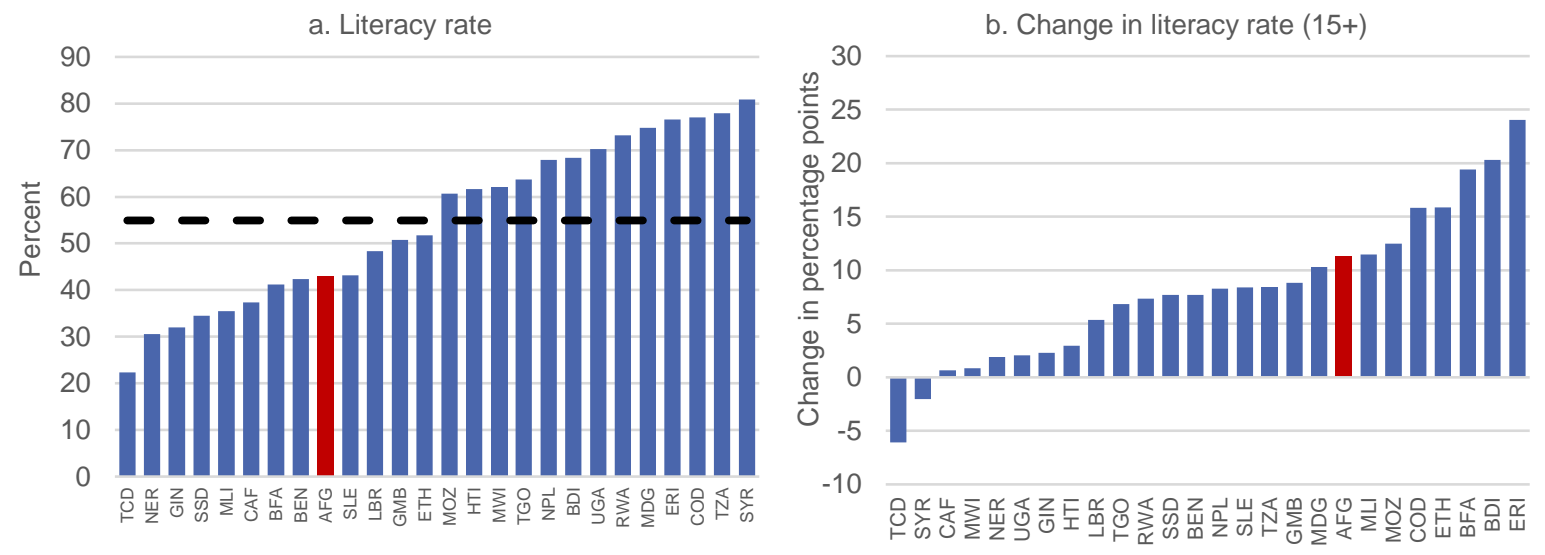

Sources: World Development Indicators, World Bank staff calculations

Note: Change is calculated as the difference between earliest and latest available data-points between 2002-2018. Time periods therefore vary by country.

${ }^{7}$ World Development Indicators 
Figure 15: Fertility rates have rapidly decreased

a. Births per woman

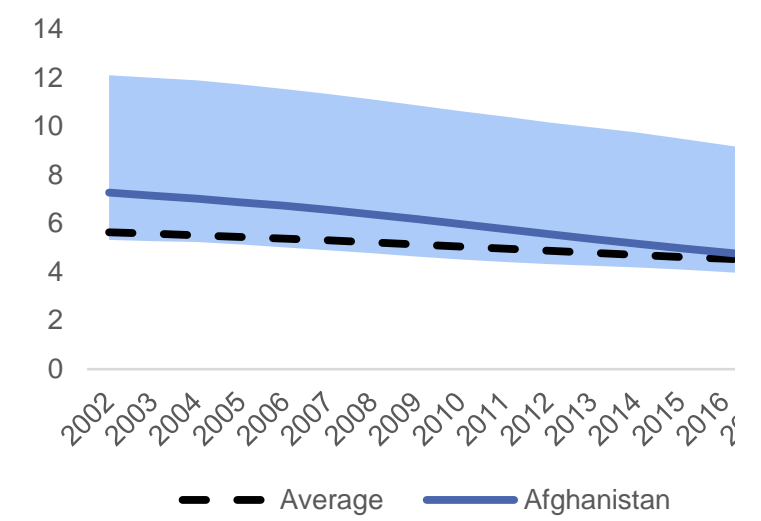

b. Change in births per woman

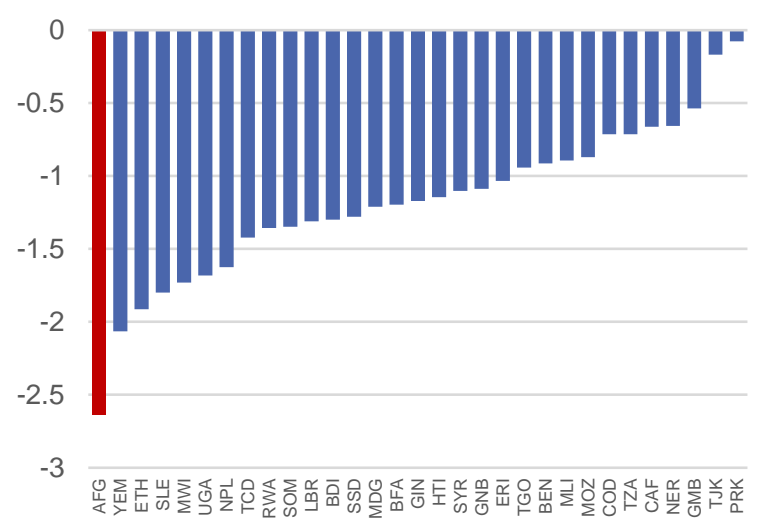

Sources: World Development Indicators, World Bank staff calculations

Note: Change is calculated as the difference between earliest and latest available data-points between 2002-2018. Time periods therefore vary by country.

Outcomes have improved for women
While women and girls continue to face major and unacceptable disadvantages in Afghanistan, important gains have been achieved. There is no significant difference by gender in measures of healthcare access, such as immunization rates.

Important gaps in education access remain. But, until recently, enrollment rates for girls were increasing more rapidly than for boys, substantially reducing the gap in access to education. While the female secondary enrolment rate increased from around six percent in 2003 to 39 percent in 2017, the ratio of females per male enrolled in secondary education increased from 0.2 to 0.6. Attendance statistics show a similar positive trajectory, with the ratio of females per male attending secondary education increasing from 0.4 to 0.5 since $2007 .{ }^{8}$

Women are also increasingly represented in the public service and politics. Approximately 21 percent of all civil servants are now women, up from negligible numbers in 2001. Around sixteen percent of civil servants in the senior management group level are female (grades one and two). ${ }^{9}$ Afghanistan now has strong women's representation in politics, from zero representation in 2001. Around 27 percent of parliamentary seats are held by women, higher than the average for low-income countries.

${ }^{8}$ ALCS data $(2008,2017)$

${ }^{9}$ NSIA Statistical Yearbook 2019 


\section{AFGHANISTAN'S DEVELOPMENT GAINS}

Figure 16: Females have increased access to education

a. Primary enrollment

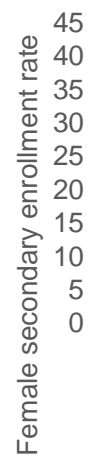

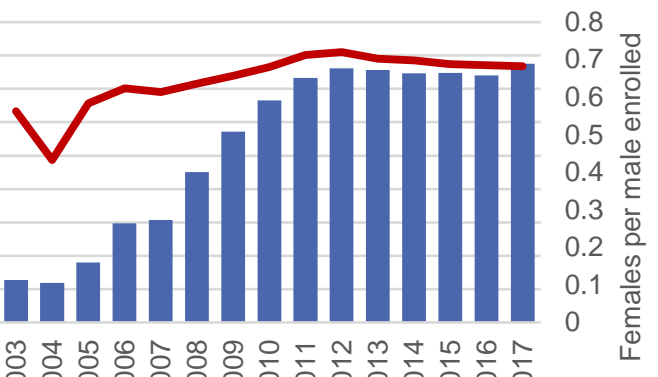

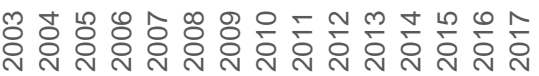

Female Enrollment Rate (LHS)

Females Per Male Enrolled (RHS) a. Secondary enrollment

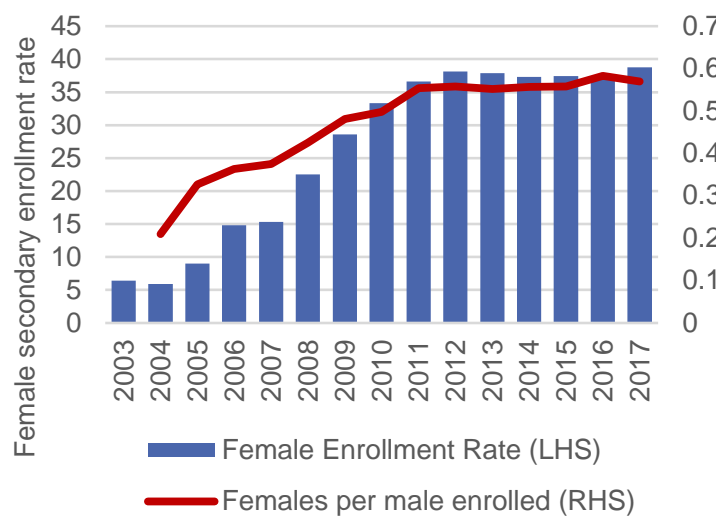

Sources: World Development Indicators, World Bank staff calculations

Figure 17: Women have radically improved political representation Percentage of seats held by women in parliament

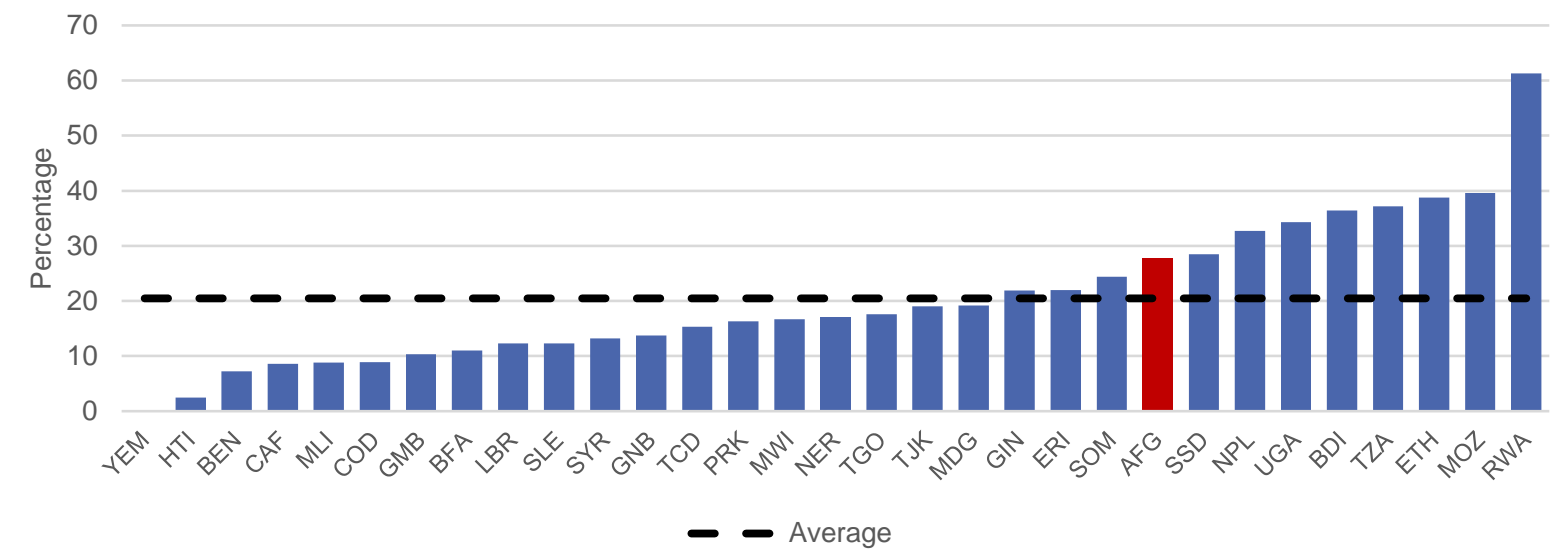

Sources: World Development Indicators, World Bank staff calculations

\section{Challenges and Implications}

\author{
Afghanistan \\ continues to face \\ major challenges in \\ governance
}

While overall macroeconomic management has been sound and development outcomes have generally improved, Afghanistan continues to face major challenges of governance. Institutions remain weak and corruption is widespread, feeding into grievances that drive conflict.

It is difficult to accurately measure the strength of institutions and governance. However, available data suggests that Afghanistan continues to perform poorly relative to other low-income countries, with little progress over time. The World Bank Country Policy and Institutional Assessments (CPIA) measure the quality of policies and institutions in all developing countries based on assessments by country experts drawing on a wide range of third-party data-sources. CPIA scores for Afghanistan against 'protection of property rights and rule-based governance' and 'transparency, accountability, and corruption in the public sector' show poor 
performance against other low-income countries and a deterioration in performance since 2005.

These findings are consistent with survey evidence showing increased prevalence of and concern about corruption. In the latest 2019 Asia Foundation Survey of the Afghan People, 97 percent of respondents believed that corruption was a problem for Afghanistan (up from 94 percent in 2006) and 91 percent believed that corruption was a problem in daily life (up from 73 percent in 2006).

Figure 18: Governance remains weak CPLA scores $(0-6$, bigher $=$ better $)$

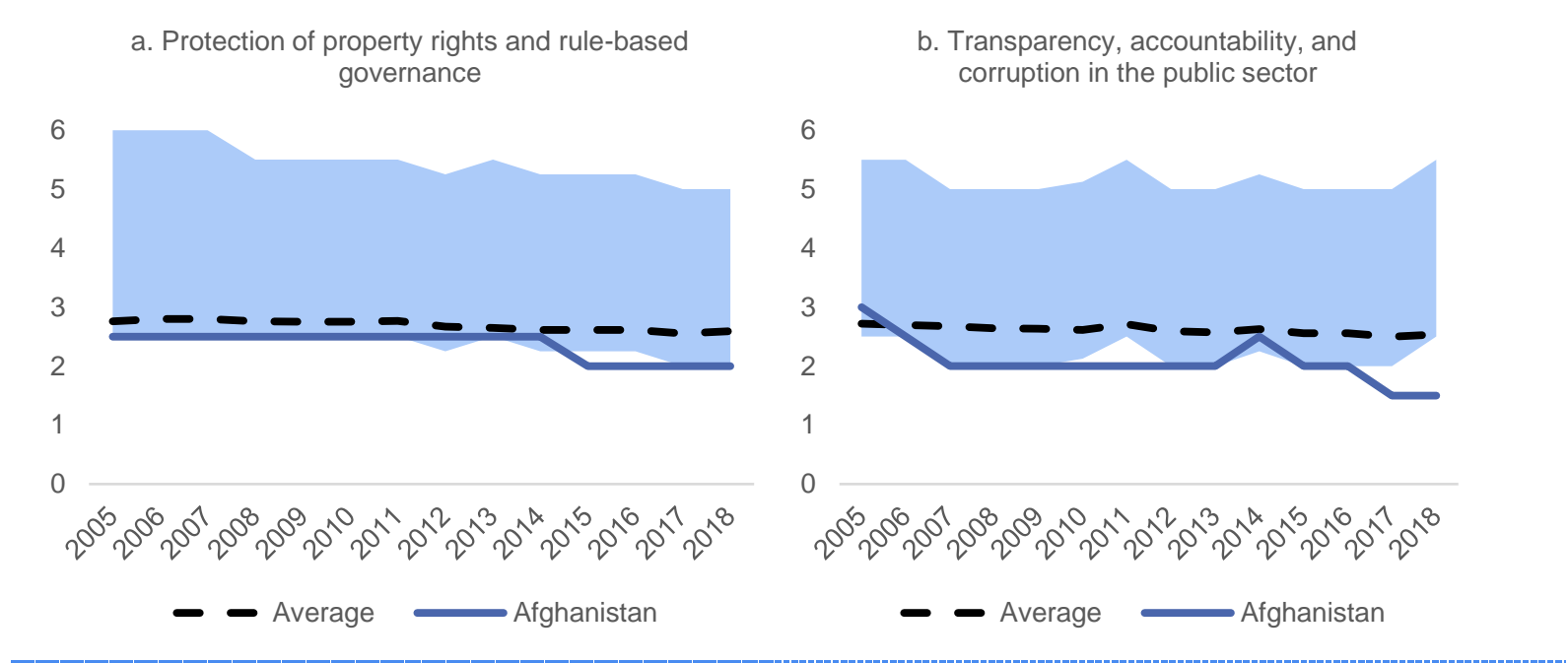

Sources: World Development Indicators, World Bank staff calculations

Gains remain fragile

Self-reliance remains a long-term goal

Continued grant support is needed...
Many development indicators have shown deterioration since 2012, reflecting economic slow-down, increasing insecurity, periods of political instability, and the impacts of negative weather shocks related to climate change. Poverty rates have increased, employment outcomes have deteriorated, and there has been some reversal of gains in access to services, with the widening of gender gaps.

While levels of civilian aid have recently declined, Afghanistan remains heavily reliant on international grant support. Grants continue to finance around 75 percent of total public expenditure and nearly 90 percent of security expenditure. Grants finance nearly half of the government budget. Further modest increases in tax revenues are possible through improvements in policy and administration. But tax revenues are now close to the average for low-income countries, and substantial additional revenue expansion will only come with accelerated economic growth over the medium-term.

The development gains that Afghanistan has achieved over recent years will therefore only be sustained if reductions in grant support are gradual and carefully calibrated. A precipitous reduction in civilian grants would undermine the capacity of government to sustain service delivery, leading to deteriorations in education, health, and well-being. Rapid reductions in security grants would lead to either a decline in security sector capabilities or a deterioration in 
development outcomes. Without revenue growth, Government can only take on a larger share of security spending by squeezing out spending on services.

...but will depend on In order to maintain the confidence of the international community and improvements in governance.

provision of international grant support, Government needs to take decisive action to address corruption and improve governance. Efforts should be taken in partnership between Government and the international community to: i) identify specific and measurable goals for anti-corruption and institutional strengthening that represent shared priorities; and ii) mobilize coordinated efforts to achieve those goals, drawing on international assistance as needed. 


